\title{
Synthesis of Some N-Alkyl and N-Aryl Amides as Potential Central Nervous System-Active Anticonvulsant Agents
}

\author{
Afolabi 0 Ezekiel*1, Agwom M Francis ${ }^{1}$, Kindala T Junior ${ }^{1,2}$ and Bot J Kim ${ }^{1}$ \\ ${ }^{1}$ Department of Pharmaceutical Chemistry, Faculty of Pharmaceutical Sciences, University of Jos, Nigeria \\ ${ }^{2}$ Department of Chemistry, Faculty of Sciences, University of Kinshasa, DR Congo
}

Submission:March 28, 2018; Published:April 16, 2018

"Corresponding author: Francis M Agwom, Department of Pharmaceutical Chemistry, Faculty of Pharmaceutical Sciences, University of Jos, Nigeria, Tel: 2348135377 878; Email: agwom2020@gmail.com

\begin{abstract}
Background: Epilepsy affects about 0.5 to $1 \%$ of the world's population. The perfect anti-epileptic drug is as yet unavailable. A carefully balance between toxicity site of most available anti-epileptic agent and their seizure activity are mostly done before uses. New and safe anticonvulsant drugs are urgently needed. Most drugs in current usage have developed based on optimization of lead compounds, either isolated from the screening of natural products, or modified from hormone or transmitter whose activity is being studied.

Methods: We selectively chose alkyl and aryl groups around the amide-link that is derived from both aliphatic and aromatic acids and amines. The chemical structures of different carboxamides obtained were confirmed using elemental analysis and spectroscopic techniques including $1 \mathrm{H}-\mathrm{NMR},{ }^{13} \mathrm{C}-\mathrm{NMR}$, IR and Mass spectroscopy. The acidity functions of all the synthesized carboxamides were calculated online using Advanced Chemistry Development pKa Data Base (ACD/pKa DB), and their anticonvulsant activities were determined after intraperitoneal and oral administration to rat and mice by Maximum Electric Shock (MES) and subcutaneous Metrazol (scMET) induced seizure methods.

Results: Ten new carboxamides were synthesized by Schotten-Baumann method. The elemental analysis and spectroscopic data on each of the compounds were in agreement with the proposed structures. The pKa values of all the investigated compounds fell within the CNS-Active optimal range of 13.50 and 15.50. Correlation Analysis shows that the CNS protective indexes (Maximum Electric Shock and subcutaneous Metrazol) used in this work was poorly correlated with the calculated pKa-values. Both, LogP and MR were respectively correlated at $r=0.732$, $\mathrm{n}=9$ and at $\mathrm{r}=0.847, \mathrm{n}=9$ for PIMES, at 0.01 significant level (2-tailed test), but were not significantly correlated for scMET. These findings are important because MES (which measures electrical stimulation of the brain) and scMET (which measures chemical stimulation of the brain) actually measure different activities in the brain even though they both show the same symptom of convulsion.
\end{abstract}

Keywords: Anticonvulsant; Carboxamides, Maximum electric shock; Subcutaneous metrazol

Abbreviations: EEG: Electroencephalogram; CAT: Computerized Axial Tomography; MRI: Magnetic Resonance Imaging; GABA: $\gamma$-Amino Butyric Acid; EAA: Excitatory Amino Acid; NMDA: N-Methyl-D-aspartate; CHN: Carbon, Hydrogen and Nitrogen; MES: Maximal Electroshock Seizure; scMET: Subcutaneous Metrazol Seizure

\section{Introduction}

Convulsion condition is characterized by violent, uncontrolled spasmodic contractions and relaxations of the voluntary muscles. Convulsions may be a symptom resulting from various conditions and diseases, such as epilepsy, uremia, eclampsia, rabies, tetanus, strychnine poisoning, and cerebral tumour [1]. They are usually accompanied by loss of consciousness. Epilepsy is a brain disorder in which a person has repeated seizures (convulsions) over time. Seizures are episodes of disturbed brain activity that cause changes in attention or behaviour. Epilepsy is a chronic neurological condition (central nervous system) activity characterized by recurrent seizures $[2,3]$. There are many types of seizures and their symptoms can vary from a momentary disruption of the senses, to short periods of unconsciousness or staring spells, to convulsions. Epilepsy can be caused by many different conditions that affect a person's brain. Often no definite cause can be found [3].

An epileptic seizure is a transient symptom of excessive or synchronous neuronal activity in the brain [4]. It can manifest as an alteration in mental state, tonic or clonic movements, convulsions, and various other psychic symptoms. The medical 
syndrome of recurrent, unprovoked seizures is termed epilepsy, but seizures can occur in people who do not have epilepsy. About $4 \%$ of people will have an unprovoked seizure by the age of 80 and only $30 \%$ to $40 \%$ [5] or according to another study $50 \%$ chance of a second one [6]. Treatment may reduce the chance of a second one by as much as half [5]. Seizure types are organized according to whether the source of the seizure within the brain is localized (partial or focal onset seizures) or distributed (generalized seizures). Partial seizures are further divided on the extent to which consciousness is affected (simple-partial and complex-partial seizures). If consciousness is unaffected, then it is a simple partial seizure; otherwise it is a complex partial seizure.

A partial seizure may spread within the brain, a process known as secondary generalization. Generalized seizures are divided according to the effect on the body, and they all involve loss of consciousness. These include absence, myoclonic, clonic, tonic, tonic-clonic, and atonic seizures [7]. It can be difficult to distinguish a seizure from other conditions causing a collapse, abnormal movements or other seizure manifestations. A 2007 evidence-based review from the American Academy of Neurology and the American Epilepsy Society recommends an electroencephalogram (EEG), brain wave activity and brain imaging with Computerized Axial Tomography (CAT) scan or Magnetic Resonance Imaging (MRI) scan in the work-up. MRI is more sensitive in a first apparently unprovoked seizure. Blood tests, lumbar puncture or toxicology screening can be helpful in specific circumstances suggestive of an underlying cause like meningitis or drug overdose, but there is insufficient evidence to support their routine use in the work-up of an adult with an apparently unprovoked first seizure [8].

Differentiating a seizure from other conditions such as syncope can be difficult. In addition, $5 \%$ of patients with a positive tilt table test may have seizure-like activity that seems to be due to cerebral hypoxia. A major seizure can sometimes be confused with a heart attack and can take days to discover. A convulsion (sometimes called a grand mal seizure) that involves the whole body (is generalized) is the most dramatic type of seizure, causing rapid, violent movements and sometimes loss of consciousness. These sometimes can start with focal movements (those involving one specific part of the body) and progress to generalized movements. Convulsions occur in about five out of every hundred people at some time during childhood. By contrast, petit mal seizures (also called absence attacks) are momentary episodes associated with a vacant stare or a brief (one or two seconds) lapse of attention. These occur mainly in young children and may be so subtle that they are not noticed until they begin affecting schoolwork [7,9].

Febrile convulsions (seizures caused by high fever) occur in three or four out of every hundred children between infancy and age five. They rarely occur after five years of age, however, and half of all children who have one febrile convulsion never have another. A febrile convulsion can cause reactions as mild as a rolling of the eyes or stiffening of the limbs, or as startling as a generalized convulsion with twitching and jerking movements that involve the whole body. Febrile convulsions usually last less than five minutes, and ordinarily the child's behavior quickly returns to normal. The risk of developing epilepsy later in life is extremely low [10]. A convulsion is a medical condition where body muscles contract and relax rapidly and repeatedly, resulting in an uncontrolled shaking of the body. Convulsion is often a symptom of an epileptical seizure; the term convulsion is sometimes used as a synonym for seizure. However, not all epileptic seizures lead to convulsions, and not all convulsions are caused by epileptic seizures. Convulsions are also consistent with an electric shock. Convulsions may also be referred to as fits in some instances [11].

The goal of management in epilepsy is to make patients completely seizure-free without side effects. Currently, this goal can be achieved fully in only about one-half of the 50 million people in the world with epilepsy [12]. Epilepsy is not a benign condition. Uncontrolled epilepsy produces significant morbidity and mortality. Even infrequent seizures put a patient at risk of sudden death and compromise employability and other social functions. In the past two decades several rational approaches have been applied to the development of anti-epileptic drugs. They provide a higher yield of more effective and more targeted drugs for epilepsy. Such studies suggest that different structures of the anticonvulsants act at different receptor sites and in fact a division into at least three classes, according to effects on seizures and interaction at receptor sites has been proposed.

The Class I anticonvulsants act at the neuronal voltagedependent sodium channel, [13-15], the Class II anticonvulsants act at $\gamma$-amino butyric acid (GABA) receptors, [15-17], the Class III anticonvulsants act by interacting with Excitatory Amino Acid (EAA) receptors, particularly those for N-Methyl-Daspartate (NMDA) [18,19]. Other mechanism and approaches to understanding and controlling seizures are under investigation [20-23]. The potential risk of a new anti-epileptic drug however has to be weighed against the potential risk of continuing seizures and the potential for the new drug to control those seizures. One must balance carefully the need for seizure control and the resulting toxicity of the anti-epileptic agent. The perfect antiepileptic drug is as yet unavailable; until it is, physicians must be aware of individual variations with regard to drug response and efficacy. In order to verify the hypothesis that observed CNSActivity of amides is due to some physicochemical properties (e.g. ionisation constant); where transport and steric factors are not overwhelming. It is intended to synthesis and characterizes a number of potential CNS-active model compounds. Screening their anticonvulsant activity using Maximum Electric Shock and subcutaneous Metrazol induced seizure methods, and Use computer to generate and correlate some physicochemical properties with the biological activity. 


\section{Materials and Methods}

\section{General Procedure for the Synthesis of Carboxamides}

The acyl-chlorides and the amines, and all others chemicals used were purchased from the Aldrich Chemical Company, Inc. The Schotten-Baumann method of preparing amides was used to synthesis all the amides $[26,27]$. A solution of the appropriate amine $(0.03 \mathrm{M})$ in $55 \mathrm{~mL}$ of tetrahydrofuran was added to $200 \mathrm{~mL}$ of $20 \% \mathrm{w} / \mathrm{v}$ aqueous potassium carbonate in a 1litre three-necked round bottomed flask. The flask was immersed in an ice bath on a magnetic stirrer, equipped with a magnetic bar, an air condenser (carrying a drying tube to exclude moisture), an addition funnel with a stopper and a thermometer immersed in the solution. A solution of the appropriate acyl chloride $(0.033 \mathrm{M})$ in $35 \mathrm{~mL}$ of tetrahydrofuran was added drop wise over 50 minutes. The mixture was allowed to stir overnight and warm to ambient temperature. The mixture was transferred to a separatory funnel and extracted with Chloroform $(3 \times 100 \mathrm{~mL})$. The extracts were combined, and washed with water, $10 \%$ aqueous $\mathrm{HCl}$, saturated aqueous $\mathrm{NaHCO}_{3}$, and water successively.

The washed extract was dried over magnesium sulphate and the solvent was removed under vacuum. The resulting residue was purified by recrystallization from methanol and the homogeneity of the product was confirmed by TLC analysis using Dichloromethane/Acetonitrile (5:1) solvent system on precoated silica gel plate. The melting point and the yield for each compound synthesised were also determined. All the compounds synthesized were subjected to spectral (H-NMR, C-NMR and MS) and elemental analyses of carbon, hydrogen and nitrogen (CHN) (Figures $1 \& 2$ ).<smiles>[R1]Cc1ccc(C(=O)NN[R2])cc1</smiles><smiles>[R3]C(=O)Cl</smiles><smiles>[R3]C(=O)Nc1c(C)cccc1C</smiles><smiles>[R3]NC([R1])=O</smiles>

Figure 1: Scheme of synthesis of compounds.

\begin{tabular}{|c|c|c|c|c|c|c|c|}
\hline $\mathbf{R}_{1}$ & $\mathbf{R}_{2}$ & Compound & $\mathbf{R}_{\mathbf{3}}$ & Compound & $\mathbf{R}_{4}$ & $\mathbf{R}_{\mathbf{5}}$ & Compound \\
\hline $\mathrm{CH}_{3}$ & $\mathrm{H}_{2} \mathrm{C}=\mathrm{CH}$ & 1 & $\mathrm{H}_{2} \mathrm{C}=\mathrm{CH}$ & 5 & $\mathrm{H}_{2} \mathrm{C}=\mathrm{CH}$ & $\mathrm{C}_{6} \mathrm{H}_{5}$ & 7 \\
\hline $\mathrm{H}$ & $\mathrm{H}_{2} \mathrm{C}-\mathrm{CH}$ & 2 & $\mathrm{H}_{3} \mathrm{C}-\mathrm{H}_{\mathrm{H}}=\mathrm{CH}$ & 6 & $\mathrm{H}_{3} \mathrm{C}-\underset{\mathrm{H}}{\mathrm{C}}=\mathrm{CH}$ & $\mathrm{C}_{6} \mathrm{H}_{5}$ & 8 \\
\hline $\mathrm{CH}_{3}$ & $\mathrm{H}_{2} \mathrm{C}-\underset{\mathrm{H}}{\mathrm{C}}=\mathrm{CH}_{2}$ & $\mathrm{H}_{2}$ & & & $\mathrm{H}_{2} \mathrm{C}=\mathrm{CH}$ & $\mathrm{CH}_{2} \mathrm{C}_{6} \mathrm{H}_{5}$ & 9 \\
\hline $\mathrm{H}$ & $\mathrm{H}_{2} \mathrm{C}-\mathrm{H}=\mathrm{CH}_{2}$ & 4 & & & & & \\
\hline
\end{tabular}




\section{Experimental}

N-cyclopropyl-2-methylbenzamide (Compound 1): A solution of $0.03 \mathrm{M}$ cylopropylamine in $55 \mathrm{~mL}$ of tetrahydrofuran was reacted with $0.033 \mathrm{M}$ solution of 2-methylbenzoyl chloride in $35 \mathrm{~mL}$ of tetrahydrofuran in accordance with the SchottenBaumann method. The procedure and the work-up, described under the preparation of carboxamides were followed to get $2.36 \mathrm{~g}$ (45\% yield) of $\mathrm{N}$ - cyclopropyl-2-methylbenzamide (Compound 1) with a melting point of $110-112 \mathrm{oC} .{ }^{1} \mathrm{H}-\mathrm{NMR}\left(200 \mathrm{MHZ}, \mathrm{CDCl}_{3^{\prime}}\right.$,

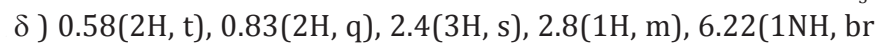
s), $7.15(1 \mathrm{ArH}, \mathrm{q}), 7.26(3 \mathrm{H}, \mathrm{q}),(1.8$, and 3.68 are THF solvent peaks); Elemental Analysis calculated for $\mathrm{C}_{11} \mathrm{H}_{13} \mathrm{NO}(\%)$ : C 75.40, H 7.48, N 7.99. Found: C 75.21, H 7.43, N 7.89; MS fragmentation peaks: $175[\mathrm{M}]^{+}, 147,132,119$ [Base Peak], 111, 98, 81,70, 56, 43.

N-allyl-2-methylbenzamide (Compound 2): A solution of $0.03 \mathrm{M}$ allylamine $(\mathrm{Y})$ in $55 \mathrm{~mL}$ of tetrahydrofuran was reacted with $0.033 \mathrm{M}$ solution of 2-methylbenzoyl chloride (T) in $35 \mathrm{~mL}$ of tetrahydrofuran in accordance with the Schotten-Baumann method. The procedure and the work-up, described under the preparation of carboxamides were followed to get 2.63g (50\% yield) of $\mathrm{N}$ - allyl-2-methylbenzamide (Compound 2) with a melting point of 58-60oC. ${ }^{1} \mathrm{H}-\mathrm{NMR}\left(200 \mathrm{MHZ}, \mathrm{CDCl}_{3}, \delta\right) 2.334$ $(3 \mathrm{H}, \mathrm{s}), 3.8(2 \mathrm{H}, \mathrm{t}), 5.12(2 \mathrm{H}, \mathrm{t}$ cis/trans), $5.81(1 \mathrm{H}, \mathrm{m}$ cis, trans), $6.46(1 \mathrm{NH}, \mathrm{br} \mathrm{s}), 7.15(2 \mathrm{ArH}, \mathrm{q}), 7.25(2 \mathrm{ArH}, \mathrm{t})(1.8$, and 3.68 are THF solvent peaks); Elemental Analysis calculated for $\mathrm{C}_{11} \mathrm{H}_{13} \mathrm{NO}$ (\%): C 75.40, H 7.48, N 7.99. Found: C 74.57, H 7.46, N 7.64; MS fragmentation peaks: $175[\mathrm{M}]^{+}, 160,147,132,119[\mathrm{EI}(20 \mathrm{eV})$ Base Peak], 108(CI), 105, 91[EI (70eV) Base Peak], 84, 69, 56/55.

N- allylbenzamide (Compound 3): A solution of $0.03 \mathrm{M}$ allylamine $(\mathrm{Y})$ in $55 \mathrm{~mL}$ of tetrahydrofuran was reacted with $0.033 \mathrm{M}$ solution of benzoyl chloride (B) in $35 \mathrm{~mL}$ of tetrahydrofuran in accordance with the Schotten-Baumann method. The procedure and the work-up, described under the preparation of carboxamides were followed to get an oily mass of $2.37 \mathrm{~g}$ (49\% yield) of $\mathrm{N}$ - allylbenzamide (Compound 3 ). ${ }^{1} \mathrm{H}-\mathrm{NMR}$ (200MHZ, $\mathrm{CDCl}_{3}, \delta$ ) $3.98(2 \mathrm{H}, \mathrm{dd}), 5.1$ (2H, q cis/trans), 5.81 (1H, m cis/trans), $6.85(1 \mathrm{NH}, \mathrm{br}$ s), $7.35(3 \mathrm{ArH}, \mathrm{m}), 7.8(2 \mathrm{ArH}$, d), (1.78, and 3.68 are THF solvent peaks); Elemental Analysis calculated for $\mathrm{C}_{10} \mathrm{H}_{11} \mathrm{NO}$ (\%): C 74.51, H 6.88, N 8.69. Found: C 74.61, H 6.89, N 8.25; MS fragmentation peaks: $161[\mathrm{M}]^{+}, 146$, 133, 118, 105[Base Peak], 94(CI), 77, 69, 56, 51, 41, 39.

N- (2, 6- dimethylphenyl) acrylamide (Compound 4): A solution of $0.03 \mathrm{M} \mathrm{2,6-dimethylphenylamine} \mathrm{(M)} \mathrm{in} 55 \mathrm{~mL}$ of tetrahydrofuran was reacted with $0.033 \mathrm{M}$ solution of acryloyl chloride (A) in $35 \mathrm{~mL}$ of tetrahydrofuran in accordance with the Schotten-Baumann method. The procedure and the work-up, described under the preparation of carboxamides were followed to get 5.20g (99\% yield) of $\mathrm{N}$ - (2, 6-dimethylphenyl) acrylamide (Compound 4) with a melting point of $135-137 \mathrm{oC} .{ }^{1} \mathrm{H}-\mathrm{NMR}$ $\left(200 \mathrm{MHZ} \mathrm{CDCl}_{3}, \delta\right) 2.3(6 \mathrm{H}, \mathrm{d}), 5.8(1 \mathrm{H}, \mathrm{d}), 6.4(2 \mathrm{H}, \mathrm{d}), 6.8(1 \mathrm{NH}$, br, s) $7.15(3 \mathrm{H}, \mathrm{m})$; Elemental Analysis calculated for $\mathrm{C}_{11} \mathrm{H}_{13} \mathrm{NO}$ (\%): C 75.40, H 7.48, N 7.99. Found: C 74.94, H 7.47, N 7.91; MS fragmentation peaks: $175[\mathrm{M}]^{+}, 160,121$ [Base Peak], 106, 55.
(2E)-N-(2,6-dimethylphenyl) but-2-enamide (Compound 5): A solution of $0.03 \mathrm{M} \mathrm{2,6-dimethylphenylamine} \mathrm{(M)} \mathrm{in} 55 \mathrm{~mL}$ of tetrahydrofuran was reacted with $0.033 \mathrm{M}$ solution of crotonyl chloride (R) in $35 \mathrm{~mL}$ of tetrahydrofuran in accordance with the Schotten-Baumann method. The procedure and the work-up, described under the preparation of carboxamides were followed to get 3.12g (55\% yield) of (2E) - N - (2, 6- dimethylphenyl) but2-enamide (Compound 5) with a melting point of 169-171oC. ${ }^{1} \mathrm{H}-\mathrm{NMR}\left(200 \mathrm{MHZ}, \mathrm{CDCl}_{3}, \delta\right.$ ) $1.92(3 \mathrm{H}, \mathrm{dd}), 2.3(6 \mathrm{H}, \mathrm{d}), 6.1(1 \mathrm{H}$, d), 6.8(1NH, br s), 6.95(1H, m), 7.1(3ArH, m); Elemental Analysis calculated for $\mathrm{C}_{12} \mathrm{H}_{15} \mathrm{NO}(\%)$ : C 76.16, H 7.99, N 7.40. Found: C 75.49, H 7.91, N 7.26; MS fragmentation peaks: $189[\mathrm{M}]^{+}, 174$, 121[Base Peak], 106, 69, 41.

N- phenylacrylamide (Compound 6): A solution of 0.03M aniline (E) in $55 \mathrm{~mL}$ of tetrahydrofuran was reacted with $0.033 \mathrm{M}$ solution of acrylol chloride (A) in $35 \mathrm{~mL}$ of tetrahydrofuran in accordance with the Schotten-Baumann method. The procedure and the work-up, described under the preparation of carboxamides were followed to get $2.52 \mathrm{~g}$ (57\% yield) of Nphenyl acrylamide (Compound 6) with a melting point of 103105oC. ${ }^{1} \mathrm{H}-\mathrm{NMR}\left(200 \mathrm{MHZ}, \mathrm{CDCl}_{3}, \delta\right) 5.56(1 \mathrm{H}, \mathrm{q}), 6.4(2 \mathrm{H}, \mathrm{t})$, $7.1(1 \mathrm{H}, \mathrm{t}), 7.3(2 \mathrm{H}, \mathrm{m}), 7.65(2 \mathrm{H}, \mathrm{d}), 8.8(\mathrm{NH}, \mathrm{s}),(1.38$, and 3.8 are THF solvent peaks); Elemental Analysis calculated for $\mathrm{C}_{9} \mathrm{H}_{9} \mathrm{NO}$ (\%): C 73.45, H 6.16, N 9.52. Found: C 73.35, H 6.16, N 9.51; MS fragmentation peaks: $147[\mathrm{M}]^{+}, 135,119,106,93$ [Base Peak], 55.

N-phenylbut-2-eamide (Compound 7): A solution of $0.03 \mathrm{M}$ aniline (E) in $55 \mathrm{~mL}$ of tetrahydrofuran was reacted with $0.033 \mathrm{M}$ solution of crotonyl chloride (R) in $35 \mathrm{~mL}$ of tetrahydrofuran in accordance with the Schotten-Baumann method. The procedure and the work-up, described under the preparation of carboxamides were followed to get $2.42 \mathrm{~g}$ (50\% yield) of $\mathrm{N}$ phenyl but-2-eamide (Compound 7) with a melting point of 100103oC. ${ }^{1} \mathrm{H}-\mathrm{NMR}\left(200 \mathrm{MHZ}, \mathrm{CDCl}_{3}, \delta\right.$ ) $1.9(3 \mathrm{H}, \mathrm{d}), 6.0(1 \mathrm{H}, \mathrm{dd})$, $7.0(1 \mathrm{H}, \mathrm{q}), 7.35(5 \mathrm{ArH}, \mathrm{m}), 7.6(1 \mathrm{NH}, \mathrm{br} \mathrm{d})$; Elemental Analysis calculated for $\mathrm{C}_{10} \mathrm{H}_{11} \mathrm{NO}(\%)$ : C 74.51, H 6.88, N 8.69. Found: C 74.11, H 6.88, N 8.63; MS fragmentation peaks: $161[\mathrm{M}]_{+}, 146$, 132, 120, 93[Base Peak] 69, 41.

N- benzylacrylamide (Compound 8): A solution of $0.03 \mathrm{M}$ benzylamine $(\mathrm{Z})$ in $55 \mathrm{~mL}$ of tetrahydrofuran was reacted with $0.033 \mathrm{M}$ solution of acryloyl chloride (A) in $35 \mathrm{~mL}$ of tetrahydrofuran in accordance with the Schotten-Baumann method. The procedure and the work-up, described under the preparation of carboxamides were followed to get 2.47g (51\% yield) of N-benzylbenzamide (Compound 8) with a melting point of 59-61oC. ${ }^{1} \mathrm{H}-\mathrm{NMR}\left(200 \mathrm{MHZ}, \mathrm{CDCl}_{3}, \delta\right.$ ) 1.81 , and 3.70 are THF solvent peaks, $4.4(2 \mathrm{BzH}, \mathrm{d}), 5.57(2 \mathrm{H}, \mathrm{dd}), 6.18(1 \mathrm{H}, \mathrm{m}$, cis/trans $)$, $6.72(1 \mathrm{NH}, \mathrm{br} \mathrm{s}), 7.2(5 \mathrm{ArH}, \mathrm{m})$; Elemental Analysis calculated for $\mathrm{C}_{10} \mathrm{H}_{11} \mathrm{NO}(\%)$ : C 74.51, H 6.88, N 8.69. Found: C 74.32, H 6.78, N 8.53; MS fragmentation peaks: $161[\mathrm{M}]^{+}$[Base Peak], 144, 133, $117,106,91,77,65,55,51,39$.

N- benzylbut-2-eamide (Compound 9): A solution of $0.03 \mathrm{M}$ benzylamine $(\mathrm{Z})$ in $55 \mathrm{~mL}$ of tetrahydrofuran was reacted with $0.033 \mathrm{M}$ solution of crotonyl chloride (R) in $35 \mathrm{~mL}$ 
of tetrahydrofuran in accordance with the Schotten-Baumann method. The procedure and the work-up, described under the preparation of carboxamides were followed to get $2.73 \mathrm{~g}(52 \%$ yield) of N-but-2-eamide (Compound 9) with a melting point of 110-112oC. ${ }^{1} \mathrm{H}-\mathrm{NMR}\left(200 \mathrm{MHZ}, \mathrm{CDCl}_{3}, \delta\right) 1.85$ (3H, dd cis/trans), $4.55(2 \mathrm{BzH}, \mathrm{d}), 5.78(1 \mathrm{NH}, \mathrm{br}$ s), $5.8(1 \mathrm{H}, \mathrm{q}$ cis/trans $), 6.8(1 \mathrm{H}$, $\mathrm{s}$ cis/trans), 7.35 (5ArH, m); Elemental Analysis calculated for $\mathrm{C}_{11} \mathrm{H}_{13} \mathrm{NO}$ (\%): C 75.40, H 7.48, N 7.99. Found: C 74.81, H 7.47, N 7.89; MS fragmentation peaks: $175[\mathrm{M}]^{+}, 160[\mathrm{EI}(20 \mathrm{eV})$ Base Peak], 131, 117, 106, 91, 79, 77, 69[EI (70eV) Base Peak], 51, $41,39$.

\section{Anticonvulsant Testing Procedures}

There are two well-documented tests that are generally used as models for assessing anticonvulsant activity. These are the Maximal Electroshock Seizure (MES) test and the Subcutaneous Metrazol Seizure (scMET) test. In the MES test an electrical current is administered via corneal electrodes to induce a seizure. Drugs that prevent such electroshock seizure in mice may possibly be effective against tonic-clonic (grand mal) seizures [24]. The useful animal test (scMET test) for screening drugs possibly effective against absence (petit mal) seizure is the prevention of seizures induced by Metrazol (pentylenetetrazol) [21]. The initial anticonvulsant evaluation of the synthesized compounds was conducted by using three dose levels $(30,100$, and $300 \mathrm{mg} /$ $\mathrm{kg}$ ) and in some cases, lower doses were administered. All tests were performed on male mice weighing 18-26 g were used [25].

The animals were maintained on Purina chow and water in a colony room for several days before use. Test solutions of all compounds were prepared in a mixture of polyethylenegycol-400 and water (30:70 v/v). Animals were dosed intraperitoneally 30 min. prior to testing. Maximal Electroshock Seizures (MES) were induced by applying an alternating current of $60 \mathrm{~Hz}$ and 50 $\mathrm{mA}$ via corneal electrode. A drop of $0.9 \%$ saline was put on the eye prior to application of the electrodes. Abolition of the hind limb tonic extension component of the seizure was defined as protection in the MES test. The subcutaneous pentylenetetrazol (metrazol) Seizure Threshold Test (scMET) was conducted by administering in the posterior midline a dose of $85 \mathrm{mg} / \mathrm{kg}$ of pentylenetetrazol in a $0.5 \%$ solution.

A protection episode of clonic spasms within $30 \mathrm{~min}$. immediately following administration of the compound was observed. Neurological deficit was measured in mice by the rotorod test. The dosed animal was placed on a 1-inch diameter knurled plastic rod rotating at $6 \mathrm{rpm}$. Neurologic toxicity was recorded as the failure of the animal to remain on the rod for $1 \mathrm{~min}$. The median anticonvulsant potency (ED50) and toxicity (TD50) were calculated from the dose-effect data. The ionization constant (pKa), Molar reactivity (MR) and LogP data for all the synthetic compounds were calculated using ACD/Labs (ACD/ Labs, version 8.0; Advanced Chemistry Development: Toronto, Canada).

\section{Results And Discussion}

The result of anticonvulsant screening for all the compounds synthesized is presented in (Tables 1-3). Summary of Data for Correlational Study are presented in (Table 4). Correlation Equations that are significant at the 0.01 level (2-tailed) were used for prediction of Anticonvulsant Activity The acidity of all the prepared carboxamides were within the predicted $\mathrm{pKa}$ working range (13.50 to 15.50 ). In view of our hypothesis that observed CNS-Activity of amides is due to such physicochemical property like ionization constant ( $\mathrm{pKa}$ ), where transport and steric factors are not overwhelming, we expected a correlation between anticonvulsant activity and the pKa-value of the selected carboxamides. The correlation with pKa1 has shown $r_{2}$ $=-0.250$ for PIMES and $\mathrm{pKa}_{2}$ has shown $\mathrm{r}^{2}=0.232$ for PIMES. Also $\mathrm{pKa}_{1}$ has shown $\mathrm{r}_{2}=0.090$ for PIscMET and for $\mathrm{pKa} 2 \mathrm{r}_{2}=$ 0.426 for PIscMET (Figure 3).

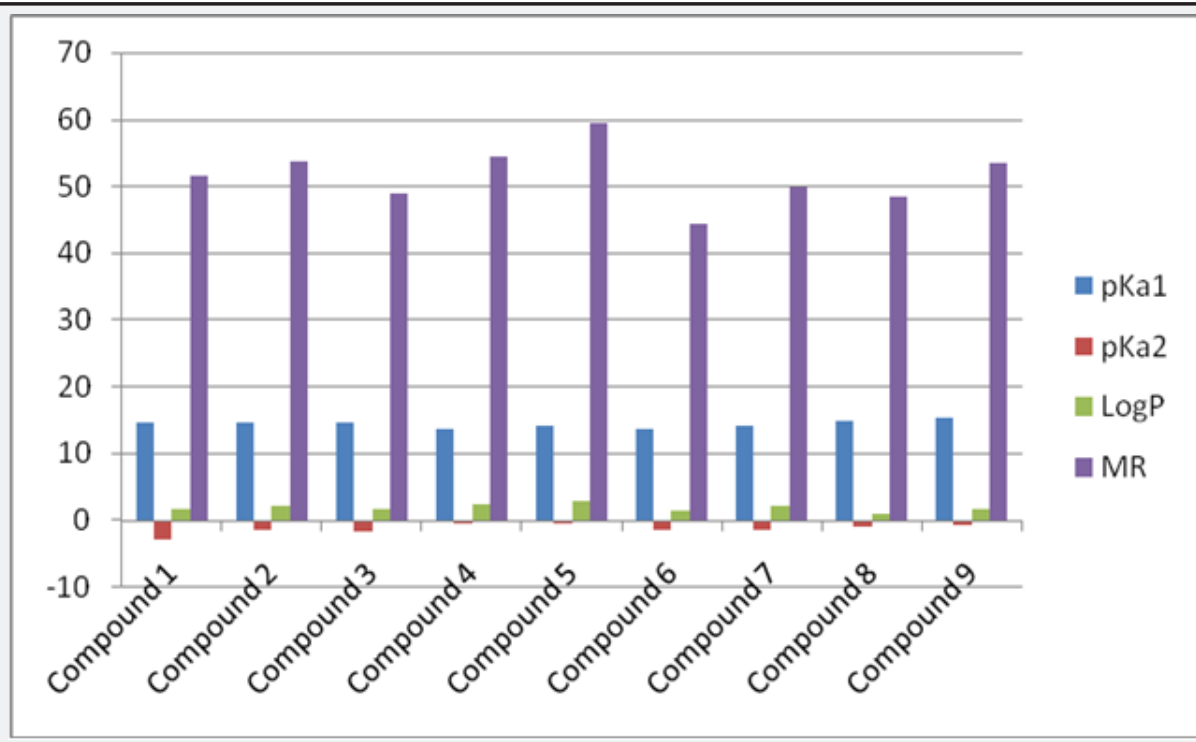

Figure 3: Summary of Data for Correlational Study. 
Table 1: Anticonvulsant identification in Mice after intraperitoneal administration.

\begin{tabular}{|c|c|c|c|c|c|c|c|c|}
\hline \multirow[t]{2}{*}{ Compound } & \multirow{2}{*}{$\begin{array}{c}\text { Dose } \\
\text { (mg/Kg) }\end{array}$} & \multicolumn{2}{|c|}{ MES Test } & \multicolumn{2}{|c|}{ scMET Test } & \multicolumn{2}{|c|}{ TOX } & \multirow{2}{*}{$\begin{array}{c}\text { ASP } \\
\text { Classification }\end{array}$} \\
\hline & & $0.5 h$ & $4 h$ & $0.5 \mathrm{~h}$ & $4 h$ & $0.5 \mathrm{~h}$ & $4 h$ & \\
\hline \multirow{3}{*}{ Compound 1} & 30 & $0 / 1$ & $0 / 1$ & $0 / 1$ & $0 / 1$ & $0 / 4$ & $0 / 2$ & \\
\hline & 100 & $3 / 3$ & $0 / 3$ & $0 / 1$ & $0 / 1$ & $0 / 8$ & $0 / 4$ & \\
\hline & 300 & $1 / 1$ & $1 / 1$ & $1 / 1$ & $1 / 1$ & $4 / 4 \mathrm{~S}$ & $0 / 2$ & \\
\hline \multirow{3}{*}{ Compound 2} & 30 & $0 / 1$ & $0 / 1$ & $0 / 1$ & $0 / 1$ & $0 / 4$ & $0 / 2$ & \multirow{3}{*}{1} \\
\hline & 100 & $3 / 3$ & $0 / 3$ & $0 / 1$ & $0 / 1$ & $0 / 8$ & $0 / 4$ & \\
\hline & 300 & $1 / 1$ & $1 / 1$ & $1 / 1$ & $0 / 1$ & $4 / 4 S$ & $0 / 2$ & \\
\hline \multirow{3}{*}{ Compound 3} & 30 & $0 / 1$ & $0 / 1$ & $0 / 1$ & $0 / 1$ & $0 / 4$ & $0 / 2$ & 1 \\
\hline & 100 & $2 / 3$ & $0 / 3$ & $0 / 1$ & $0 / 1$ & $0 / 8$ & $0 / 4$ & \\
\hline & 300 & $1 / 1$ & $0 / 1$ & $5 / 5$ & $0 / 1$ & $4 / 4$ & $2 / 2$ & \\
\hline \multirow{3}{*}{ Compound 4} & 30 & $0 / 1$ & $0 / 1$ & $0 / 1$ & $0 / 1$ & $0 / 4$ & $0 / 2$ & \multirow{3}{*}{1} \\
\hline & 100 & $3 / 3$ & $0 / 3$ & $3 / 5$ & $0 / 1$ & $1 / 8$ & $0 / 4$ & \\
\hline & 300 & $1 / 1$ & $1 / 1$ & $1 / 1 \mathrm{~S}$ & $0 / 1$ & $4 / 4 \mathrm{~T}$ & $0 / 2$ & \\
\hline \multirow{3}{*}{ Compound 5} & 30 & $0 / 1$ & $0 / 1$ & $0 / 1$ & $0 / 1$ & $0 / 4$ & $0 / 2$ & \multirow{3}{*}{1} \\
\hline & 100 & $3 / 3$ & $0 / 3$ & $0 / 1$ & $0 / 1$ & $0 / 8$ & $0 / 4$ & \\
\hline & 300 & $1 / 1$ & $0 / 1$ & $4 / 5$ & $0 / 1$ & $4 / 4$ & $0 / 2$ & \\
\hline \multirow{3}{*}{ Compound 6} & 30 & $0 / 1$ & $0 / 1$ & $0 / 1$ & $0 / 1$ & $0 / 4$ & $0 / 2$ & \multirow{3}{*}{2} \\
\hline & 100 & $0 / 3$ & $0 / 3$ & $0 / 1$ & $0 / 1$ & $0 / 8$ & $0 / 4$ & \\
\hline & 300 & $1 / 1$ & $0 / 1$ & $0 / 1$ & $0 / 1$ & $4 / 4 S$ & $0 / 2$ & \\
\hline \multirow{3}{*}{ Compound 7} & 30 & $0 / 1$ & $0 / 1$ & $0 / 1$ & $0 / 1$ & $0 / 4$ & $0 / 2$ & \multirow{3}{*}{1} \\
\hline & 100 & $3 / 3$ & $0 / 3$ & $0 / 1$ & $0 / 1$ & $0 / 8$ & $0 / 4$ & \\
\hline & 300 & $1 / 1$ & $0 / 1$ & $1 / 5$ & $0 / 1$ & $4 / 4 S$ & $0 / 2$ & \\
\hline \multirow{3}{*}{ Compound 8} & 30 & $0 / 1$ & $0 / 1$ & $0 / 1$ & $0 / 1$ & $0 / 4$ & $0 / 2$ & \multirow{3}{*}{1} \\
\hline & 100 & $3 / 3$ & $0 / 3$ & $0 / 1$ & $0 / 1$ & $0 / 8$ & $0 / 4$ & \\
\hline & 300 & $1 / 1$ & $0 / 1$ & $1 / 1$ & $0 / 1$ & $4 / 4 \mathrm{~S}$ & $0 / 2$ & \\
\hline \multirow{3}{*}{ Compound 9} & 30 & $0 / 1$ & $0 / 1$ & $0 / 1$ & $0 / 1$ & $0 / 4$ & $0 / 2$ & \multirow{3}{*}{1} \\
\hline & 100 & $2 / 3$ & $0 / 3$ & $3 / 5$ & $0 / 1$ & $0 / 8$ & $0 / 4$ & \\
\hline & 300 & $1 / 1$ & $0 / 1$ & $1 / 1$ & $0 / 1$ & $4 / 4$ & $0 / 2$ & \\
\hline
\end{tabular}

Table 2: Anticonvulsant identification in Rat after oral administration $(50 \mathrm{mg} / \mathrm{Kg})$.

\begin{tabular}{|c|c|c|c|c|c|c|c|c|c|c|c|c|c|}
\hline \multirow{2}{*}{ Compound } & \multicolumn{5}{|c|}{ MES } & \multicolumn{5}{|c|}{ TOX } & \multirow{2}{*}{$\mathbf{K}$} & \multirow{2}{*}{$\mathrm{t} 1 / 2$} & \multirow{2}{*}{ TPE } \\
\hline & $0.25 \mathrm{~h}$ & $0.5 h$ & 1h & $2 h$ & $4 h$ & $0.25 \mathrm{~h}$ & $0.5 \mathrm{~h}$ & 1h & $2 h$ & $4 h$ & & & \\
\hline Compound 1 & $0 / 4$ & 4-Jan & 4-Apr & 4-Apr & 4-Jan & $0 / 4$ & $0 / 4$ & $0 / 4$ & $0 / 4$ & $0 / 4$ & -1.7 & 0.4 & 0.5 \\
\hline Compound 2 & 4-Feb & 4-Feb & 4-Jan & $0 / 4$ & $0 / 4$ & $0 / 4$ & $0 / 4$ & $0 / 4$ & $0 / 4$ & $0 / 4$ & 4.05 & 0.17 & - \\
\hline Compound 3 & 4-Jan & $0 / 4$ & $0 / 4$ & $0 / 4$ & $0 / 4$ & $0 / 4$ & $0 / 4$ & $0 / 4$ & $0 / 4$ & $0 / 4$ & 1.74 & 0.4 & 0.25 \\
\hline Compound 4 & 4-Apr & 4-Apr & 4-Apr & 4-Mar & 4-Jan & $0 / 4$ & $0 / 4$ & $0 / 4$ & $0 / 4$ & $0 / 4$ & 0.38 & 1.82 & 0.25 \\
\hline Compound 5 & 4-Jan & 4-Feb & $0 / 4$ & $0 / 4$ & $0 / 4$ & $0 / 4$ & $0 / 4$ & $0 / 4$ & $0 / 4$ & $0 / 4$ & 3.22 & 0.21 & 0.5 \\
\hline Compound 6 & 4-Jan & $0 / 4$ & 4-Jan & 4-Jan & $0 / 4$ & $0 / 4$ & $0 / 4$ & $0 / 4$ & $0 / 4$ & $0 / 4$ & 1.87 & 0.37 & 0.25 \\
\hline Compound 7 & $0 / 4$ & $0 / 4$ & 4-Jan & $0 / 4$ & $0 / 4$ & $0 / 4$ & $0 / 4$ & $0 / 4$ & $0 / 4$ & $0 / 4$ & 0.74 & 0.94 & 1 \\
\hline Compound 8 & 4-Feb & 4-Jan & 4-Feb & 4-Feb & 4-Jan & $0 / 4$ & $0 / 4$ & $0 / 4$ & $0 / 4$ & $0 / 4$ & 0.1 & 6.61 & 0.25 \\
\hline Compound 9 & 4-Mar & 4-Mar & 4-Feb & $0 / 4$ & $0 / 4$ & $0 / 4$ & $0 / 4$ & $0 / 4$ & $0 / 4$ & $0 / 4$ & 4.19 & 0.16 & 0.5 \\
\hline
\end{tabular}




\section{Organic and Medicinal Chemistry International Journal}

Table 3: Summary of Anticonvulsant Activity of synthetic compounds and of some known Anti epileptic drugs.

\begin{tabular}{|c|c|c|c|c|c|}
\hline CMP(ID) & $\begin{array}{l}\mathrm{TD}_{50} \\
\text { (TOX) }\end{array}$ & $\begin{array}{l}\mathrm{ED}_{50} \\
\text { (MES) }\end{array}$ & $\begin{array}{c}\text { ED }_{50} \\
\text { (scMET) }\end{array}$ & $\begin{array}{c}\mathrm{PI}= \\
\text { TD/ED(MES) }\end{array}$ & $\begin{array}{c}\mathrm{PI}= \\
\mathrm{TD} / \mathrm{ED}(\mathrm{scMET})\end{array}$ \\
\hline Compound 1 & 235.23 & 226.57 & NP & 1.04 & - \\
\hline Compound 2 & 235.23 & 112.46 & 299.92 & 2.09 & 0.78 \\
\hline Compound 3 & 235.23 & 226.57 & 191.99 & 1.04 & 1.23 \\
\hline Compound 4 & 242.49 & 112.46 & 173.18 & 2.16 & 1.4 \\
\hline Compound 5 & 235.23 & 173.18 & 235.23 & 1.36 & 1 \\
\hline Compound 6 & 235.23 & 226.57 & 235.23 & 1.04 & 1 \\
\hline Compound 7 & 235.23 & 173.18 & 987.42 & 1.36 & 0.24 \\
\hline Compound 8 & 235.23 & 173.18 & 299.92 & 1.36 & 0.78 \\
\hline Compound 9 & 235.23 & 226.57 & 173.18 & 1.04 & 1.36 \\
\hline Phenobarbital & 69 & 21.8 & 13.2 & 3.17 & 5.23 \\
\hline Phenytoin & 65.5 & 9.5 & NA & 6.89 & 11.6 \\
\hline Trimethadone & 819 & 627 & 300 & 1.31 & 2.73 \\
\hline Ethosuximide & 442 & 1000 & 130 & 0.441 & 3.39 \\
\hline Diazepam & 7.3 & 19.1 & 0.165 & 0.382 & 44.2 \\
\hline Carbamazepine & 71.6 & 8.81 & NA & 8.13 & - \\
\hline Valproic Acid & 69 & 272 & 149 & 1.57 & 2.86 \\
\hline
\end{tabular}

Table 4: Correlation Equation of MES and scMET Protective Index with pKa, LogP and MR.

\begin{tabular}{|c|c|c|c|c|}
\hline Eqn & Equation & $\mathbf{n}$ & $\mathbf{s}$ & $\mathbf{r}^{2}$ \\
\hline 1 & $\begin{array}{c}\mathrm{PI}(\mathrm{MES})= \\
0.667+0.368 \log \mathrm{P}\end{array}$ & 9 & 0.415 & 0.485 \\
\hline 2 & $\begin{array}{c}\mathrm{PI}(\mathrm{MES})= \\
-0.837+0.043 \mathrm{MR}\end{array}$ & 9 & 0.430 & 0.421 \\
\hline 3 & $\begin{array}{c}\mathrm{PI}(\mathrm{MES})=4.995- \\
0.250 \mathrm{pKa}_{1}\end{array}$ & 9 & 0.445 & -0.343 \\
\hline 4 & $\begin{array}{c}\mathrm{PI}(\mathrm{MES})= \\
1.675+0.232 \mathrm{pKa}_{2}\end{array}$ & 9 & 0.436 & 0.393 \\
\hline 5 & $\begin{array}{c}\mathrm{PI}(\mathrm{scMET})= \\
0.914+0.030 \log \mathrm{P}\end{array}$ & 8 & 0.410 & 0.049 \\
\hline 6 & $\begin{array}{c}\mathrm{PI}(\mathrm{scMET})= \\
0.024+0.018 \mathrm{MR}\end{array}$ & 8 & 0.400 & 0.224 \\
\hline 7 & $\begin{array}{c}\mathrm{PI}(\mathrm{scMET})= \\
0.202+0.054 \mathrm{pKa}_{1}\end{array}$ & 8 & 0.409 & 0.090 \\
\hline 8 & $\begin{array}{c}\mathrm{PI}(\mathrm{scMET})= \\
1.317+0.332 \mathrm{pKa}_{2}\end{array}$ & 8 & 0.371 & 0.426 \\
\hline
\end{tabular}

$\mathrm{n}=$ number of compounds, $\mathrm{r}=$ correlation coefficient, $\mathrm{s}$ - standard deviation.

This results confirms that PIMES and PIscMET used in this work are poorly correlated with the calculated pKa-value; and shows that the carboxamides may be acting as intact molecules at the receptor site. The other physicochemical properties used in this work are $\log P$ and MR. $\log P$ is a measure of solubility property of the drug molecule while MR is a measure of the volume occupied by the drug molecule in space. Both, LogP and MR have shown a little significantly correlation at $r^{2}=$ 0.465 for PIMES/LogP and at $\mathrm{r}^{2}=0.421$ for PIMES/MR, at the
0.01 level (2-tailed test). Even these two parameters (LogP and MR) are poorly correlated for PIscMET Protective Index. This conclusion is quite important in that it confirms the previous conclusion that MES (which measures electrical stimulation of the brain) and scMET (which measures chemical stimulation of the brain) actually measures different activities in the brain even though they both show the same symptom of convulsion in the experimental animal. 
The anticonvulsant testing of the carboxamides revealed that the compound 4 has the best activity against both electroshock and metrazol-induced seizures with the following data: PIMES=2.16, PIscMET=1.40, pKa1=13.65, pKa2=-0.45, $\log \mathrm{P}=2.54$, and $\mathrm{MR}=54.53$.

\section{Conclusion}

The concept of Parallel Synthesis was successfully applied in this work to synthesize all compounds. The correlational analyses have shown that both protective indices PIMES or PIscMET used in this work are poorly correlated with the calculated pKa-value. The results obtained with LogP and MR has shown a correlation only with PIMES.

\section{References}

1. Mohamed Kamal Ibrahim, Ashraf Abd Elrahman, Rezk Ayyad, Khaled El Adl, Ahmed Mansour, et al. (2013) Design and synthesis of some novel 2-(3-methyl-2-oxoquinoxalin-1(2H)-yl)-N-(4-(substituted)phenyl) acetamide derivatives for biological evaluation as anticonvulsant agents. Bulletin of Faculty of Pharmacy, Cairo University 51(1): 101111.

2. Naveen Yadav, Manav Malhotra, Vikramdeep Monga, Sagun Sharma, Jainendra Jain, et al. (2012) Synthesis, characterization, and pharmacological evaluation of new GABA analogs as potent anticonvulsant agents. Medicinal Chemistry Research 21(9): 22082216.

3. Qian Ying Tan, Uday Kundap, Yatinesh Kumari, Mohd Farooq Shaikh (2015) A Review on Natural Therapy for Seizure Disorders. Pharmacy \& Pharmacology International Journal 3(2): 00051.

4. Robert Fisher, Walter van Emde Boas, Warren Blume, Christian Elger, Pierre Genton, et al. (2005) Epileptic seizures and epilepsy: definitions proposed by the International League Against Epilepsy (ILAE) and the International Bureau for Epilepsy (IBE) Epilepsia 46(4): 470-472.

5. Susan Herman (2004) Single Unprovoked Seizures. Current Treatment Options in Neurology 6(3): 243-255.

6. Anne Berg (2008) Risk of recurrence after a first unprovoked seizure. Epilepsia 49(1): 13-18.

7. Robert Fisher, Helen Cross, Jacqueline French, Norimichi Higurashi, Edouard Hirsch, et al. (2017) Operational classification of seizure types by the International League Against Epilepsy: Position Paper of the ILAE Commission for Classification and Terminology. Epilepsia 58(4): 522-530.

8. Krumholz A, Wiebe S, Gronseth G, Shinnar S, Levisohn P, et al. (2007) Practice Parameter: evaluating an apparent unprovoked first seizure in adults (an evidence-based review): report of the Quality Standards Subcommittee of the American Academy of Neurology and the American Epilepsy Society. Neurology 69(21): 1996-2007.

9. Lourdes Vélez, Linda M Selwa, (2003) Seizure Disorders in the Elderly. American Family Physician 67(2): 325-332.

10. Steven P Shelov, Tanya R Altmann (2004) Caring for Your Baby and Young Child: Birth to Age 5. American Academy of Paediatrics.

11. Michael Buenor Adinortey, Isaac K Galyuon, Nicholas Oteng Asamoah (2013) Trema orientalis Linn. Blume: A potential for prospecting for drugs for various uses. Pharmacognosy Rev 7(13): 67-72.
12. Hauser WA, Anneger JF, Kurland LT (1991) The Epidemiological Survey of Epilepsy. Epilepsia 32: 429-445.

13. Symthies JR (1980) Structure Activity Relationship. In Glaser, G H Penry JK and Woodbury DM (Eds.) Antiepileptic Drugs: Mechanism of Action. New York: Raven Press, USA, p. 58-81.

14. Mena Abdelsayed, Stanislav Sokolov (2013) Voltage-gated sodium channels: pharmaceutical targets via anticonvulsants to treat epileptic syndromes. Channels (Austin) 7(3): 146-152.

15. APG Nikalje, M Ghodke, A Girbane (2011) GABA Modulating Agents: A Brief Review. Asian Journal of Biological Sciences 4(3): 201-220.

16. Chapman AG (1982) Mechanism of Anticonvulsant action of valporate. Progress in Neurobiology 19: 315-359.

17. Olsen RW (1986) Midbrain GABA receptor deficit in genetic animal models of epilepsy. In Nistico G Morsilli, PI Lloyd, KG Fariello, Engel J (Eds.) Neurotransmitters, seizures and epilepsy. New York: Raven Press, USA, pp. 279-291.

18. Chapman AG, Meldrum BS (1991) Excitatory amino acid in Epilepsy and as Novel anti-epileptic drugs. In F Pissani, E Perucca, G Avanzini, A Richens (Eds.) New Anti-Epileptic Drugs. Amsterdam p. 39-48.

19. Rogawski MA (2011) Revisiting AMPA receptors as an antiepileptic drug target. Epilepsy Currents. 11(2): 56-63.

20. Bojore JG Lee R, Lomax P (1986) Neuropeptides; Anticonvulsant and convulsant Mechanism in Epileptic Model Systems and in Human. In AV Delgado-Escueta (Ed.) Advances in Neurology, New York: Raven Press, USA, pp. 489-500.

21. Gloor P (1988) Neurophysiological mechanism of generalized spike and wave discharge and its implication for understanding absence seizures. In MS Myslobodsky and AF Mirsky (Eds.) Elements of Pettimal Epilepsy. New York: Peter Long, USA, pp. 159-210.

22. Anderson VB, Hauser WA (1993) Genetics. In Laidlaw J, Richens A, Chadwick D (Eds.) A textbook of epilepsy, (4 ${ }^{\text {th }}$ edn.); Edinburgh: Churchill Livingstone, USA, pp. 447-476.

23. Johannessen Landmark (2008) Antiepileptic drugs in non-epilepsy disorders: relations between mechanisms of action and clinical efficacy. CNS Drugs 22(1):27-47.

24. Brown WC, DO Schiffman, EA Swinyad, LS Goodman (1953) Comparative assay of Antiepileptic drugs by 'Psychomotor' seizure test and minimal electroshock threshold test. Journal of Pharmacology and Experimental Therapeutics107: 273-283.

25. Passman R, Horvath G, Thomas J, Kruse J, Shah A, et al. (2003) Clinical spectrum and prevalence of neurologic events provoked by tilt table testing. Archives of Internal Medicine 163(16): 1945-1948.

26. Ezekiel Afolabi Olabisi, Junior Kindala Tinatina (2016) Synthesis and characterization of two novel compounds: 2-Methyl-N-prop2-ynylbenzamide and N-prop-2-ynylbenzamide. IOSR Journal of Applied Chemistry (IOSR-JAC) 9 (7): 39-41.

27. Ezekiel Afolabi O, Francis Agwom M, Junior Kindala T (2016) Synthesis and characterization of two new carboxamides compounds: n-prop2-ynylacrylamide and n-prop-2-ynylbut-2-enamide. International Journal of Multidisciplinary Research and Information 2(6): 395-397. 
(C) Commons Attribution 4.0 License BY DOI: 10.19080/OMCIJ.2018.06.555688
Your next submission with Juniper Publishers will reach you the below assets

- Quality Editorial service

- Swift Peer Review

- Reprints availability

- E-prints Service

- Manuscript Podcast for convenient understanding

- Global attainment for your research

- Manuscript accessibility in different formats ( Pdf, E-pub, Full Text, Audio)

- Unceasing customer service

Track the below URL for one-step submission https://juniperpublishers.com/online-submission.php 